\title{
Challenges Facing the Use and Adoption of Mobile Phone Money Services
}

\author{
Odoyo Collins Otieno ${ }^{1, *}$, Samuel Liyala ${ }^{1}$, Benson Charles Odongo ${ }^{2}$, Silvance Abeka ${ }^{1}$ \\ ${ }^{1}$ School of Informatics and Innovative Systems, Jaramogi Oginga Odinga University of Science and Technology, Kenya \\ ${ }^{2}$ Department of Special Needs Education and Early Childhood Development, Jaramogi Oginga Odinga University of Science and \\ Technology, Kenya
}

Copyright $\odot 2016$ by authors, all rights reserved. Authors agree that this article remains permanently open access under the terms of the Creative Commons Attribution License 4.0 International License

\begin{abstract}
The Mobile phone banking idea was initially born out of the intention to reach the unbanked rural poor. However, there still existed mobile phone money service divide, highly skewed against the rural poor population. This paper was therefore seeking to explore challenges facing mobile phone money services. Qualitative research technique was used. Further, both primary and secondary data was used. The study was conducted in Homa Bay region in Kenya, using ethnography research design. The study established that mobile phone money use and adoption had numerous challenges that had hindered it. Most affected by the challenges were the mobile phone money users and potential users from the rural poor communities. Some of the challenges included lack of national ID cards by potential users, few mobile phone money agents, inadequate cash and e-floats by the agents, awareness and lack of information on how to access and operate certain features in mobile money platform, as well as language barrier.
\end{abstract}

Keywords Mobile Phone Money, Mobile Phone Users, Challenges, Mobile Phone Money Use, Mobile Phone Money Adoption

\section{Introduction}

Mobile money services were introduced by private telecommunication providers in several countries around the world especially in Africa, Asia, and Latin America [1]. The concrete design of mobile money services may not be similar; however the general idea was to enable cheap and reliable money transfers between people that have access to a mobile phone.

Mobile phone payment however, has been seen only to be a normal practice in a few countries, despite its huge potential. The lack of worldwide dissemination of a service with such a huge potential is an indication that successful cases are not clearly understood, and as a consequence, are not being easily replicated in other parts of the world. A further indication that, lessons are not being learnt from the places where the system has been successfully adopted and benefits are enormously seen. Further, the obstacles to its adoption in most countries could have not been investigated deeply enough to allow implementation strategies to be employed on the basis of reliable business models [2]. These issues therefore need to be clarified, to enhance the potential social and economic impacts of mobile money which can be more effectively measured and this would persuade policy makers to create favourable regulatory environments for enhancing the practice of mobile phone money [2].

\section{Literature Review}

A study by $\mathrm{Yu}$ [3] enriched current knowledge about what affects individuals to use mobile banking, employed the Unified Theory of Acceptance and Use of Technology (UTAUT) to investigate what impacts people to adopt mobile banking. Through sampling 441 respondents, this study empirically established that individual intention to adopt mobile banking was significantly influenced by social influence, perceived financial cost, performance expectancy, and perceived credibility, in their order of influencing strength. The behavior was considerably affected by individual intention and facilitating conditions. As for moderating effects of gender and age, the study discovered that gender significantly moderated the effects of performance expectancy and perceived financial cost on behavioral intention, and the age considerably moderated the effects of facilitating conditions and perceived self-efficacy on actual adoption behavior. The study was however keen on addressing challenges affecting mobile banking alone. This study did not look into the challenges that affect the adoption of mobile phone money services in payment of services, goods as well as shopping.

An article by Yankee Group [4] stated that m-commerce is facing many obstacles as an emerging market, particularly in 
the United States of America. For example, in addition to lack of standards, cost and speed issues, a Yankee Group survey suggested that U.S. consumers were not convinced that they wanted or need mobile services and many think it is simply too complicated [4]. This is in contrast to other global markets in Asia and Europe where - going online means reaching for a mobile handset and not just turning on a Personal Computer (P.C.). Many challenges remained to the adoption of new payment systems such as mobile phone money [5]. The very basic challenge was that, mobile money providers must sell the system to both the sellers and consumers simultaneously. Providers must convince the sellers to build infrastructure at the point of sale which would eventually enable payment using mobile money platform. To succeed, they must persuade enough consumers to adopt mobile money, that the sellers find the system profitable [5].

The challenge with mobile money in Finland was that all of these players (excluding customers and government) had to agree on the distribution of the financial profits, which was typically a very slow process [6]. It was also yet unclear that who would actually run the mobile money service of the future [7]. According to a research by Mallat [8], Finnish consumers found SMS based payments to be complex and slow to use. SMSs were heavily criticized because the message formats were often complicated, the service numbers are difficult to remember and instructions could be hard to find. Therefore Mallat suggested that SMS was not the best possible technology used for mobile money in Finland. Another disadvantage of this type of system was that it required infrastructure support from the mobile network. Payments could not be made if there was no mobile phone reception. Basically it meant that SMS based payments may not work in remote districts. Even stormy weather could cause problems to the cellular network infrastructure making it impossible to make SMS-based payments [9]. This study mainly looked at the complex nature of SMS as the main challenge.

A Report by Central Bank of Nigeria, [10], stated that, the major challenge affecting mobile money in Nigeria was the regulatory framework. The report further posits that 'it was developed to conform to international best practice and standards'. It also specifies the necessary functionalities expected of any mobile money service in Nigeria. The regulatory framework in Nigeria applied to all activities of the participants, involved in the provision of mobile money services which included; service providers, infrastructure providers, solution providers, scheme operators and consumers [10]. In contrast to Kenya, the regulatory framework between both countries could be described as two extreme fields, Where Nyaoma [11], posits that Kenya had an open and controlled regulatory environment, while Nigeria had a restricted regulatory environment. This study however, focused majorly on challenges brought by regulations.

According to Kenya's Economic Survey of the year 2003 [12], the major Information Systems and mobile technology challenges in the Kenya consisted of poor and inadequate information systems, inadequate IT infrastructure, limited skills in ICT, lack of appreciation of ICT, technology weaknesses exhibited by heavy reliance on inappropriate and obsolete technology, lack of skills on modern technology, lack of awareness of the changing technology, poor dissemination mechanisms between and among the various levels of enterprises, and poor technology linkages between the private and public sector institutions. The report, however, was not comprehensive enough, as it did not look at the level and trends of adoption among the different age groups as well as how the rural-urban conditions affected technology adoption.

A study conducted in Nairobi, Kenya by Nyaga and Ogollah [13] that sought to explore the challenges that mobile network operators faced in penetrating the Mobile Money Transfer (MMT) in Kenya which was dominated by one player. The study assumed that there were challenges and constraints that limited the involvement of competitive MMT services which were attributed to the internal and external environment of the Mobile Network Operator (MNO). The study was significant as it was seeking to unearth knowledge and provide insight to competing firms to enter into the MMT services market which had been experiencing significant growth over the years. The study established that customers consider the perceived usefulness of a product before adopting mobile money transfer service. The study further, established that the system uptime was an integral consideration in provision of Mobile Money Transfer service. On product and services differentiation, the study established that product and services offered impact greatly in a customer's choice of Mobile Money Transfer service. The study also established that innovative product attracts a customer to a Mobile Money Transfer service. On customer experience, the study established that initial customer experience with the service providers determines if the customer would remain as a service user or use would move to a competing product. Therefore on overall, the study established that customer experience played a key role in mobile money transfer. 
Table 1. Sample Size

\begin{tabular}{|c|c|c|c|c|c|c|}
\hline \multicolumn{7}{|c|}{ FOCUS GROUP DISCUSSION SAMPLE SIZE } \\
\hline & & \multicolumn{2}{|c|}{ Male } & \multicolumn{2}{|c|}{ Female } & \multirow{2}{*}{ Total } \\
\hline & & Youth & Old & Youth & Old & \\
\hline URBAN & Homa Bay Town & 4 & 4 & 4 & 4 & 16 \\
\hline \multirow{2}{*}{ RURAL } & Ndhiwa Sub County & 2 & 2 & 2 & 2 & 8 \\
\hline & Rangwe Sub County & 2 & 2 & 2 & 2 & 8 \\
\hline \multicolumn{2}{|r|}{ Total } & 8 & 8 & 8 & 8 & 32 \\
\hline \multicolumn{7}{|c|}{ INTERVIEW SAMPLE SIZE } \\
\hline & & \multicolumn{2}{|c|}{ Male } & \multicolumn{2}{|c|}{ Female } & \multirow{2}{*}{ Total } \\
\hline & & Youth & Old & Youth & Old & \\
\hline URBAN & Homa Bay Town & 2 & 2 & 2 & 2 & 8 \\
\hline \multirow{2}{*}{ RURAL } & Ndhiwa Sub County & 1 & 1 & 1 & 1 & 4 \\
\hline & Rangwe Sub County & 1 & 1 & 1 & 1 & 4 \\
\hline \multicolumn{2}{|r|}{ Total } & 4 & 4 & 4 & 4 & 16 \\
\hline \multicolumn{2}{|r|}{ GRAND TOTAL } & 12 & 12 & 12 & 12 & 48 \\
\hline
\end{tabular}

\section{Materials and Methodology}

Qualitative research technique was used because it was appropriate to help understand the dynamics of paper. Since the study was based on the perceptions of mobile phone money users as well as potential user, their perceptions were qualitative in nature that could be better collected, analysed and presented qualitatively. Further, both primary and secondary data were used, that were generated from the field using semi-structured interviews, observations and focus group discussions, as well as literature of studies that had been done by other scholars. These tools of data collection were adopted since the study also was based on ethnography research design. A total of 48 participants participated in this study, 32 taking part in four (4) different focus group discussions, each group with 8 participants each, while the remaining 16 participants were interviewed. Observation took place concurrently during the entire period of this study. Also out of 48 participants, 24 of them were male and the other 24 were female. Further, 24 [participants were from communities parts of the study area, while the remaining 24 participants were from the urban communities as illustrated in table 1. The study was conducted in Homa Bay region in Kenya, using ethnography research design. Ethnography was adopted because it lends itself to the study of the beliefs, social interactions, and behaviors of small societies, involving participation and observation over a period of time, and the interpretation of the data collected. Its main benefit is its depth, and therefore the contribution of rich insight to the subject being studied. Being a paper that looked at the challenges affecting mobile phone money technology adoption and use, it was very important to compare the results of this study to results of other studies done by other scholars from different geographical areas.

\section{Results}

There existed a number of challenges affecting use and adoption of mobile phone money technology. First, the study established that there was the existence of few mobile phone money agents. There also existed limited amount of e-float that would otherwise not always effectively serve the users.

"Most of these agents would always tell you that they do not have "float" when you would like to deposit money in your mobile phone or that they do not have cash when you would like to withdraw money. The only days they at least have much money and "float" to serve more customers are during market days."

It was equally difficult to find an agent having sufficient money to serve all those withdrawing large sums of money. In most case they would encourage those withdrawing, to do so in small quantities so as to allow them serve many people with the limited money resource that they had and make more profit in return.

Another challenge that influenced mobile phone money utilization in the rural settings was lack of national ID cards by some potential mobile money users as was stated during the interview;

"In this part, there are many people who still lack national ID cards, especially the young women, married in this area and are also illiterate. They do not even have mobile phones of their own and are therefore not users' of M-Pesa, since to have a phone requires them to buy SIM card that will be registered using national ID number, and a further registration for M-Pesa that also requires them to have national ID card which they do not have."

There was lack of national identification (ID) cards 
especially by mostly ladies below the age of 30 years. Being a requirement by Communications Authority of Kenya that all Mobile Network Operators (MNO), register all their subscribers, a process that requires an individual to be in possession of national ID card, those without ID cards technically find themselves excluded from this technology, as stated by a participant in the focus group discussion;

"It is indeed true that most of our young women do not have national ID cards, that is why even now when people are registering as voters, they are shying off. What do you expect? If they can't even register as voters, these women don't have mobile phones and rely on their husbands' phones to make and receive calls as well as to send and to receive money through M-Pesa."

Another challenge was that many traders in the study area still preferred cash transactions over cashless transactions. The only traders who had enabled their businesses to accommodate mobile money in transactions were mainly in urban centers of the study area.

Another challenge was that of language barrier, especially when one sends money to a wrong person, and was forced to contact customer care who speaks in Swahili and English languages only most of the people would in many cases fail to follow up for the transaction to be reverted. When such challenges took place, in many cases mobile money agents kept off and advised the users to contact customer service on their own;

"Of late I fear sending money to friends and relatives since I sent money to a wrong person, and there was no one to help me recover the money, including the M-pesa agents who just gave me the customer care number to dial and claim the money on my own... ....customer care people also only speaks to us in either English or Swahili language, which I can't express myself in... ...this has led to many of us let go our monies whenever we send to wrong numbers."

The study further established Lack of information as another challenge facing the users in the study area, especially the rural communities. Most of the interviewees lacked the information that mobile phone money could be used as well to buy goods through the use of till numbers and payment of utility bills as long as there is a business number. This clearly came out during the interview with a mobile phone money user;

"Does it mean that even this phone of mine has got Buy goods and Pay bill options like that one of yours... .. I though such features are only available in some phones, but not like this one of mine. How do I go about these features when I want to embrace this technology?"

Most of the users were only aware of the element of sending and receiving money through mobile phone, but not the other elements. What was more surprising was that, some users had mobile phones but were surprised during the focus group discussion sessions to discover that their own phones had these mobile phone money features.

"Wow even my phone too has payment of service feature, pay bill and buy goods options. I have only been aware about sending money, withdrawing money and M-Shwari, as the only features that M-Pesa had. Thank you for having us in this activity. For sure, I have learned something really new."

This showed a clear indication that inadequate information posed as a challenge to embracing the wide range of services their mobile phone money technology could offer to them.

\section{Discussions}

Lack of ID cards by potential users was a great challenge that influenced mobile phone money use and adoption in the rural communities. A good number of potential users lacked these vital documents that were instrumental in allowing them register their cellular lines as well as registering their lines for mobile phone money services. National ID cards, being a requirement by Communications Authority of Kenya that all MNO register all their subscribers a process that requires an individual to be in possession of national ID card. This meant that those without ID cards technically found themselves excluded from the use or adoption of this technology.

Looking at the relevance of ID cards in Kenya, lack of it posed a major challenge of adopting and utilizing mobile money service in the study area. This denies community members, who were over the age of 18 years old from participating in various development activities. Mobile phone money services being one of such development activities that community members, could benefit from, also depended heavily on possession of ID cards by the users. Many people in the study area recognized the importance of using mobile phone money services, especially for remittances that was the most common element in the study area. However, the challenge they had was that, most of them still relied on mobile phones owned by their friends and relatives, as they could not be able to have phones on their own. This was due to the requirement that they had to register their cellular lines as well as register for mobile money services that depended on ID numbers for registration. It clearly came out that possession of a national ID cards, was a very significant Facilitating Condition to adopting and using mobile money.

There was a legitimate concern that some aspects of mobile phone money services were not popular, not only within the rural areas, but even within urban areas. For that reason, fewer urban dwellers used mobile phone money. Some of the challenges that had led to this according to the findings of this study included little awareness about mobile money, lack of support in vernacular languages, and, perhaps most crucially, security issues for both customers and regulators. According to The World Bank working paper [14] No. 146 "Integrity in Mobile Financial Services" 
established that security concerns were at the center around customer identification, data protection, the ability to disguise mobile transaction totals, the speed with which illicit transactions can be carried out, and the level of regulation of the service providers. These limitations could be expected to be on the decline as new technologies evolve and existing ones establish their credibility.

Even though mobile banking was especially valuable for rural regions across the world because of the lack of alternatives, its delivery depends upon overcoming several bottlenecks across the varied societies. The most pressing of these was meeting the prerequisite of mobile network coverage. Also, physical security concerns were more acute in rural areas, especially with the use of agents. Proper measures needed to be placed at the kiosks where physical transactions take place, due to the problems associated with crime and bribery. Even though transactions could be cashless, however, hard cash still needed to be available for customers, especially those who received money from friends and relatives and would like to withdraw. This was the reason why security needed to be a priority, although it might be particularly difficult in more remote areas.

The other challenge that was established especially among the rural communities was the existence of few mobile phone money agents. In addition to the few agents available in the rural parts, the agents always had limited cash and e-float to trade with. Availability of agents as well as both cash and e-floats were some of the facilitating conditions that enhanced mobile phone money adoption and use. The inadequate or lack of agents, cash as well as e-floats led to ineffective service delivery to the users of mobile phone money. The study further established that, the only days that mobile phone money agents at least had much money and e-float to serve more customers were during market days.

Delays during transactions using mobile phone money was yet another major concern to the respondents though only a few people normally experienced it. Most of the users got irritated when they were forced to wait for long minutes or even hours on the event of transaction delays. Most of the users who had experienced delay in the past preferred to carry out cash transactions as opposed to experiencing delays. Many argued that this could any day be disastrous, especially in case of emergency that would require money urgently. This condition, therefore, too many people, would be a demotivator to comply with mobile phone money innovation or to adopt and use. This led to some users and potential users to have subjective view of this innovation, which negatively influenced their behavioural intention to use. The delays experienced when transacting using mobile phone money services to send, receive money, to buy goods or pay bills which also posed as another challenge. This was not specific to any part however; it was cutting across the entire study area, whether urban or rural. This discouraged many users from fully embracing mobile phone money services, especially those who were always impatient.
Balan et al., [9] established in work that one disadvantage of mobile money services was that it required infrastructure support from the mobile network operators. Further, payments could not be made if there were no mobile phone reception. Basically, this meant that SMS based payments may not work in remote places with the challenges of connectivity in terms of network. This was similar to the challenge that users at times faced on transaction delays in the study area. This indicated that network connectivity was not that perfect, since there were instances when fluctuations existed that resulted in transaction delays, which was experienced across the entire study area, both rural and urban areas alike sometimes. Balan et al., [9] further, stated that even stormy weather could cause problems to the cellular network infrastructure making it impossible to make SMS-based payments. Cellular network connectivity would therefore be considered as another facilitating condition, as it supports the use of mobile phone money service.

Many traders in the study area still preferred cash transactions over cashless transactions. Mostly, this was due to lack of trust of the mobile phone payment systems. Since this approach of transaction depends on SMS technology, most traders feared that they could become victims in the hands of individuals who may recycle a previous SMS during transaction to defraud them. Also as observation during the study exposed, it was very clear that very few traders had embraced mobile phone payment to be used by their various customers as a means of transaction. The traders who had enabled their businesses to accommodate mobile money in tractions were mainly those with businesses in urban centers. Therefore, this became a challenge especially for the users who intended to use mobile phone money payment in buying goods within the rural communities.

According to Hoofnagle, et al. [5], many challenges remained to the adoption of new payment systems such as mobile phone money and the very basic challenge was that, mobile payment providers must sell the system to both the sellers and consumers simultaneously. That is, providers must convince the sellers to build infrastructure at the point of sale which would eventually enable payment using mobile payment platform and to succeed, they must persuade enough consumers to adopt mobile payments, that the sellers find the system profitable. This clearly replicates the situation existing in the study area. In certain areas you find a few mobile money users, who would prefer to use the systems, such as it was the case of the rural parts of the study area, yet the sellers/traders did not provide the services in their premises. Whereas there also existed other places where, there were traders/sellers who had the services of mobile phone money in their businesses, but the buys were strongly glued to cash transactions. This further indicated how both the users and the traders were not ready for mobile phone money services as at the time of this study. This therefore calls for a balance in popularizing the technology among the traders/sellers as well as the buyers, 
which was lacking in the study area.

Another challenge to utilization of mobile phone money services was that of language barrier, especially when one sends money to a wrong person, and the only way out of retrieving the amount back involved contacting customer care who speaks in Swahili and English languages only, hindered many users who found themselves in such a circumstance. This meant that most of such individuals would in many cases fail to follow up for such wrong transactions to be reverted due to language barrier, as they could neither speak English nor Swahili languages used by customer care. According to the study findings, when such challenges took place, mobile phone money agents kept off and advices the users to contact customer service on their own. The study further established that most of the users who had become victims or knew about those who had suffered the same circumstances, were more cautious to send money to friends and relative for fear of sending the money to a wrong persons, yet the process of reverting transaction would require that they engaged a customer care who would use a language that they had limited knowledge about.

The findings concurred with two other studies from the economic development and practitioner literature, by Ivatury and Pickens [15] and Porteous [16], that suggested that, mobile money users in South Africa were wealthier and better educated than the average South African with a bank account, let alone the average unbanked South African. Being educated meant that they would be able express their plight whenever it required that they seek the services of customer care. Being wealthy on the other end meant that they had financial resources to deposit in their mobile phone money account for transactions. Looking at this finding, it was evident that, lack of education was one of the major challenges in the study area with respect to adopting and utilizing mobile phone money services. This therefore indicated that a more educationally empowered community or area, would easily adopt the use of mobile phone money services, since this reduces some of the barriers hindering adoption.

The study further established Lack of information as another major challenge facing the users in the study area from utilizing mobile phone money service, especially in the rural communities. This challenge influenced on whether to use or not to use mobile phone money services in the study area. Most of the people claimed to have better understanding of mobile money use, but on further interrogation, the researcher established that they were mainly aware of the aspects of sending and receiving money (remittances). Most of the mobile phone money users lacked the information that mobile phone money could as well be used to buy goods through the use of till numbers and payment of utility bills as long as the utility service provider had a business number from MNOs.

According to Kenya's Economic Survey of the year 2003 [12], the major Information Systems and mobile technology challenges in the Kenya consist of poor and inadequate information systems, inadequate IT infrastructure, limited skills in ICT, lack of appreciation of ICT, technology weaknesses exhibited by heavy reliance on inappropriate and obsolete technology, lack of skills on modern technology, lack of awareness of the changing technology, poor dissemination mechanisms between and among the various levels of enterprises, and poor technology linkages between the private and public sector institutions.

This concurs with the findings established by this study that clearly showed lack of awareness on the wide range of services offered by mobile phone money services. Majority of mobile phone money users in the study area were only aware of aspects of remittances. However, when it came to other services such as the use of Pay Bills and Buy Goods services, quite a number were surprised to realize that even their own mobile phones had the sane capabilities. This showed lack of awareness in the study area on the constantly changing technologies. Many even got stuck to obsolete methods of transaction of the emerging technologies that offered numerous benefits. This was coupled by the limited skills and knowhow by the people in the study area, to navigate various services offered by their mobile phones in order to be aware of the wide range of services that they could have access to.

\section{Conclusions}

In conclusion the study established that mobile phone money use and adoption had numerous challenges that had hindered it. Most affected by the challenges were the mobile phone money users and potential users from the rural poor communities. Some of the challenges included lack of national ID cards by potential users, few mobile phone money agents, inadequate cash and e-floats by the agents, awareness and lack of information on how to access and operate certain features in mobile money platform, as well as language barrier.

\section{REFERENCES}

[1] Must, B., \& Ludewig, K. (2010). Mobile money: cell phone banking in developing countries. Policy Matters Journal, Spring, 27-33.

[2] Beshouri, C., Chaia, A., Cober, B., \& Gravråk, J. (2010). Banking on mobile to deliver financial services to the poor. Global Financial Inclusion. McKinsey \& Company’s Social Sector office.

[3] Yu, C., (2012). Factors Affecting Individuals to Adopt Mobile Banking: Journal of Electronic Commerce Research, VOL 13, NO 2, 2012

[4] Yankee Group Research, (2002). Mobile User Survey Results Part 1: Will Next Generation Data Services Close the Value Gap? 
[5] Hoofnagle, C. J., Jennifer M. \& Li, U.S., (2012). Mobile Payments: Consumer Benefits \& New Privacy Concerns: BCLT Research Paper April 24, 2012

[6] Salonen, R. \& Suomi, M. (2010). NFC-työryhmän väliraportti. Liikenne- ja viestintäministeriö, Helsinki, June 2010. Available at http://www.lvm.fi/c/document_library/get_file?

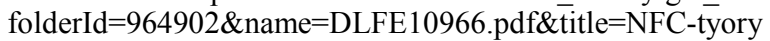
hman_valiraportti

[7] Leinonen, H. (2008). Payment habits and trends in the changing e-landscape 2010. Expository Studies A: 1112008 , Bank of Finland.

[8] Mallat, N. (2007). Exploring Consumer Adoption of Mobile Payments. A Qualitative Study. The Journal of Strategic Information Systems, 16 (4), 413-432.

[9] Balan, R. K., Ramasubbu, N., Prakobphol, K., Christin, N., \& Hong, J. (2009). mFerio: the design and evaluation of a peer-to-peer mobile payment system. MobiSys '09 Proceedings of the 7th International Conference on Mobile Systems, Applications and Services.

[10] Central Bank of Nigeria (CBN) Annual Report 2011

[11] Nyaoma, G. (2009): "Regulating mobile money: the case of M-PESA", presentation by the Director of Banking Services,
Central Bank of Kenya, at the Alliance for Financial Inclusion Global Policy Forum, Nairobi, 16 September, www.afi-global.org/en/phoca-speeches-globalpolicy-forum? download $=80 \% 3$ Agpf-2009-presentation-nyaoma

[12] Government of Kenya (2003). Economic Survey 2003. Central Bureau of Statistics Government Printers, Nairobi.

[13] Nyaga, J. N and Kennedy Ogollah, K., (2015) Challenges Facing Penetration of New Mobile Money Transfer Services In Nairobi. Journal of Economics and Finance, Volume 6, Issue 3. Ver. I, PP 26-32

[14] WORLD BANK WORKING PAPER NO. 146 Integrity in Mobile Phone Financial Services: Measures for Mitigating Risks from Money Laundering and Terrorist Financing. Viewed on $19^{\text {th }}$ February, 2016, from: http://siteresources.w orldbank.org/INTAML/Resources/WP146_Web.pdf

[15] Ivatury, G., \& Pickens, M. (2006). Mobile phone banking and low-income customers: Evidence from South Africa. Washington, DC: Consultative group to assist the poor (CGAP) and the United Nations Foundation.

[16] Porteous, D. (2007). Just how transformational is m-banking? Retrieved 10 August, 2015, from http://www.finmarktrust.or g.za/accessfrontier/Documents/transformational_mbanking.p df 